Vol. 1 No. 1, Maret 2021, hlm. 33 - 42

DOI: $\mathrm{xxxxxxxxxxxxxxxxx}$

Available online at http:// jurnal.stmikroyal.ac.id/index.php/j-com

\title{
PENERAPAN MODEL SCRUM DALAM PERANCANGAN SISTEM INFORMASI PENELITIAN DAN PENGABDIAN KEPADA MASYARAKAT
}

\author{
Edi Kurniawan ${ }^{1}$, Khairul Imtihan ${ }^{2 *}$, Ahmad Tantoni ${ }^{2}$ \\ ${ }^{1}$ Mahasiswa Prodi Teknik Informatika, STMIK Lombok \\ ${ }^{2}$ Prodi Teknik Informatika, STMIK Lombok \\ email: khairulimtihan31@gmail.com
}

\begin{abstract}
Application of the Scrum model in the design of research and community service information systems (Case study at STMIK Lombok), the Institute for Research and Community Service (LPPM) is an activity unit that functions to manage all research and community service activities carried out by lecturers in connection with the lecturer improving the quality of the lecturer. The formulation of the problem is how to design and build a research and community service information system so as to facilitate the process of submitting proposals, accepting, selecting, reviewing, approving, controlling implementation and facilitating reporting. This study uses data collection methods namely observation and interviews, while the system development method uses the Scrum method, the following is a description of the stages of software development using the Scrum method, namely: Produck Backlog, Sprint Backlog, Sprint and Working Increment of the Software. Based on the data analysis, it was concluded that the research and community service information system was designed to facilitate the submission of research proposals as well as the dedication and reporting of research and service activities being carried out by lecturers. Presentation of information in this system includes lecturer data input, input of research proposal, dedication proposal input, print decision letter and report data input.
\end{abstract}

Keywords:Information Systems Research and Community Service, SCRUM Method

\begin{abstract}
Abstrak:Penerapan model Scrum dalam perancangan sistem informasi penelititan dan pengabdian kepada masyarakat (Studi kasus di STMIK Lombok), Lembaga Penelititan dan Pengabdian pada Masyarakat (LPPM) adalah sebuah unit kegiatan yang berfungsi mengelola semua kegiatan penelititan dan pengabdian kepada masyarakat yang dilakasanakan oleh dosen dalam kaitan dengan peningkatan kualitas dosen tersebut. Adapun perumusan masalahnya bagaimana merancang dan membangun sistem informasi penelitian dan pengabdian kepada masyarakat sehingga mempermudah dalam proses pengajuan proposal, penerimaan, seleksi, review, persetujuan, pengontrolan pelaksanaan dan mempermudah pelaporan. metode pengembangan sistemnnya menggunakan metode Scrum, uraian dari tahap-tahap pengembangan perangkat lunak menggunakan metode Scrum yaitu : Produck Backlog, Sprint Backlog, Sprint dan Working Increment Of The Software. Berdasarkan analisa data yang dilakukan diperoleh kesimpulan bahwa Sistem informasi penelitian dan pengabdian kepada masyarakat ini dirancang untuk melakukan kemudahan dalam pengajuan usulan proposal penelitian maupun pengabdian dan pelaporan kegiatan penelitian dan pengabdian yang sedang dilakukan oleh dosen. Penyajian informasi dalam sistem ini meliputi input data dosen, input proposal penelitian, input proposal pengabdian, mencetak surat keputusan dan input data laporan.
\end{abstract}

Kata kunci:Sistem Informasi Penelitian dan Pengabdian kepada Masyarakat, Metode SCRUM. 
Vol. 1 No. 1, Maret 2021, hlm. 33 - 42

DOI: $\operatorname{xxxxxxxxxxxxxxxxx}$

Available online at http:// jurnal.stmikroyal.ac.id/index.php/j-com

\section{PENDAHULUAN}

Pemanfaatan akan teknologi dan informasi sangat dibutuhkan di semua bidang terutama bidang pendidikan, bahkan sistem informasi itu sendiri sudah menjadi kebutuhan pokok yang harus terpenuhi bagi suatu lembaga pendidikan untuk memajukan kualitas dan pelayanannya. Dengan diterapkannya teknologi informasi, maka kinerja karyawan disebuah instansi akan menjadi lebih baik, dan memberikan kemudahan pada pelayanan informasi.

Sistem informasi mencakup perangkat lunak (software), perangkat keras (hardware), infrastruktur, dan Sumber Daya Manusia (SDM) yang terlatih, dan saling berkaitan dalam menciptakan sebuah sistem mengolah data menjadi informasi yang bermanfaat [1].

Saat ini STMIK Lombok Praya belum mempunyai sistem informasi yang baik dalam pengelolaan dan mengorganisir data-data hasil penelitian dan pengabdian yang dilakukan oleh dosen STMIK Lombok Praya. Dari permasalahan diatas penulis bermaksud untuk merancang dan membangun sistem yang dapat mempermudah kinerja Dosen dan LPPM dalam pengoprasiannya dengan mengimplementasikan.

Dalam penelitian menggunakan metode perancangan sistem SCRUM, untuk menerapkan metode pengembangan aplikasi agile [2]. Agile merupakan metodologi pengembangan aplikasi yang memerlukan proses adaptasi. SCRUM salah satu metodologi agile paling popular, metodeologi adaptif, berulang, cepat, fleksibel dan efektif yang dirancang untuk memberikan nilai yang signifikan dengan cepat dan seluruh proyek [3].

Pemodelan sistem informasi menggunakan use case diagram [4], use case diagram menggambarkan interaksi secara sistem ekternal dan pengguna, yang didalamnya terdapat aktor yang menggunakan sistem. Black-box testing adalah teknik pengujian perangkat lunak yang berfokus pada spesifikasi fungsional dari perangkat lunak [5].

Tujuan yang ingin dicapai adalah untuk merancang dan membangun sistem informasi lembaga penelitian dan pengabdian kepada masyarakat, sehingga membantu bagian LPPM dan dosen STMIK Lombok Praya dalam pengelolaan dan pengorganisasian data-data hasil penelitian dan pengabdian kepada masyarakat.

\section{METODE}

Metode penelitian yang dilakukan pertama dalah pengumpulan data, dimana melakukan observasi untuk mendapatkan data-data yang menunjang dengan melakukan pengamatan secara langsung terhadap objek yang ada dengan maksud untuk mendapatkan data yang benar dan sesuai dengan situasi yang ada di STMIK Lombok. Melakukan tanya jawab terhadap pihak yang terkait secara langsung untuk memperoleh data yang benar dan akurat. Wawancara dapat dilakukan dengan langsung bertatap muka maupun melalui media komunikasi.

Metode penelitian yang kedua melakukan perancangan sistem dalam perancangan sistem ini ada beberapa perancangan seperti perancangan proses, perancangan struktur sistem, dan perancangan interface, metode yang digunakan dalam 
Vol. 1 No. 1, Maret 2021, hlm. 33 - 42

DOI: $\mathrm{xxxxxxxxxxxxxxxxx}$

Available online at http:// jurnal.stmikroyal.ac.id/index.php/j-com

perancangan sistem yang peneliti gunakan adalah metode SCRUM, SCRUM memiliki beberapa tahapan yang berurut yaitu : Tahapan Pre Game, Product Backlog, Game dan post Game. Rancangan flowchart usulan user LPPM dapat dilihat pada gambar 1.

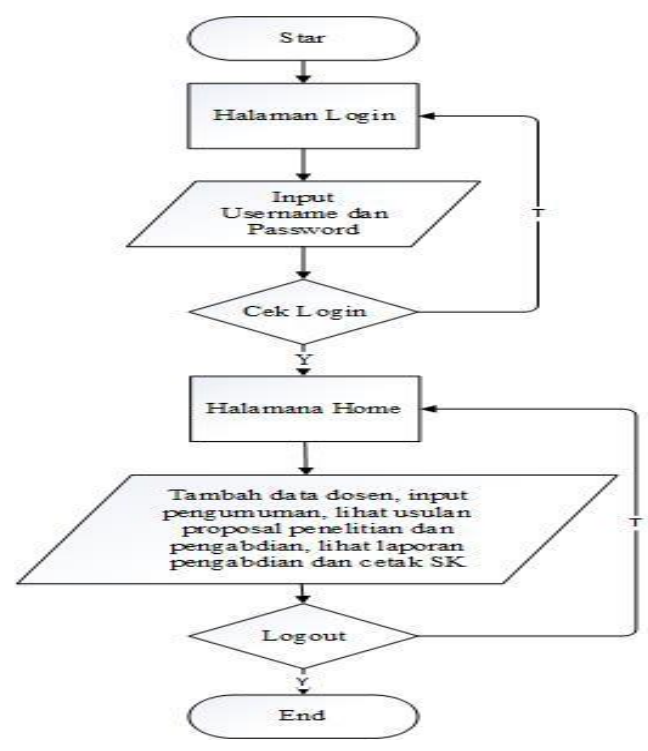

Gambar 1. Flowchart user LPPM

Rancangan flowchart usulan user dosen dapat dilihat pada gambar 2.

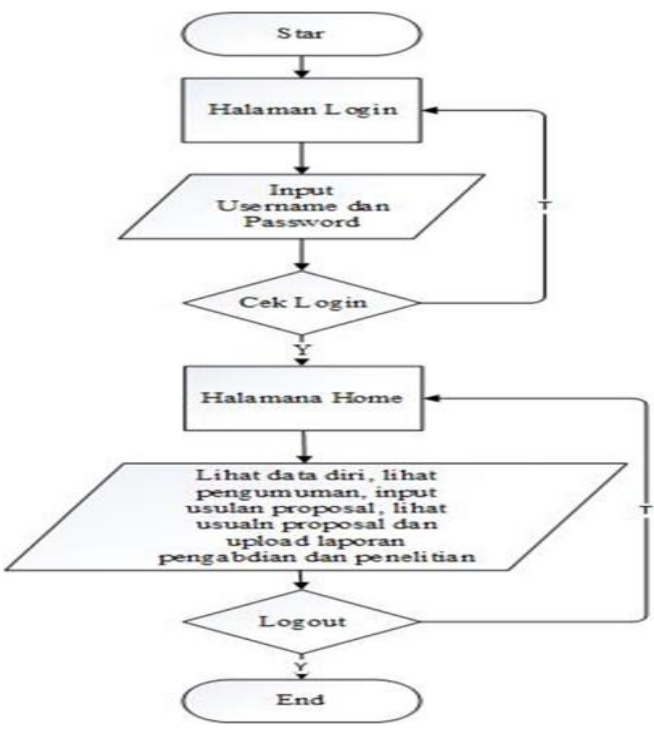

Gambar 2. Flowchart usulan user Dosen

Use case diagram merupakan gambaran umum tentang tindakan-tindakan yang dilakukan oleh actor baik actor Dosen maupun actor admin LPPM, untuk admin sendiri melakukan tindakan seperti login, mengelola data-data dosen dan kegiatan usulan serta pelaporan. Sedangkan untuk dosen hanya bisa melihat data diri, melihat 
Vol. 1 No. 1, Maret 2021, hlm. 33 - 42

DOI: $\operatorname{xxxxxxxxxxxxxxxxx}$

Available online at http:// jurnal.stmikroyal.ac.id/index.php/j-com

pengumuman, input usulan proposal, lihat usulan proposal dan upload laporan pengabdian dan penelitian.

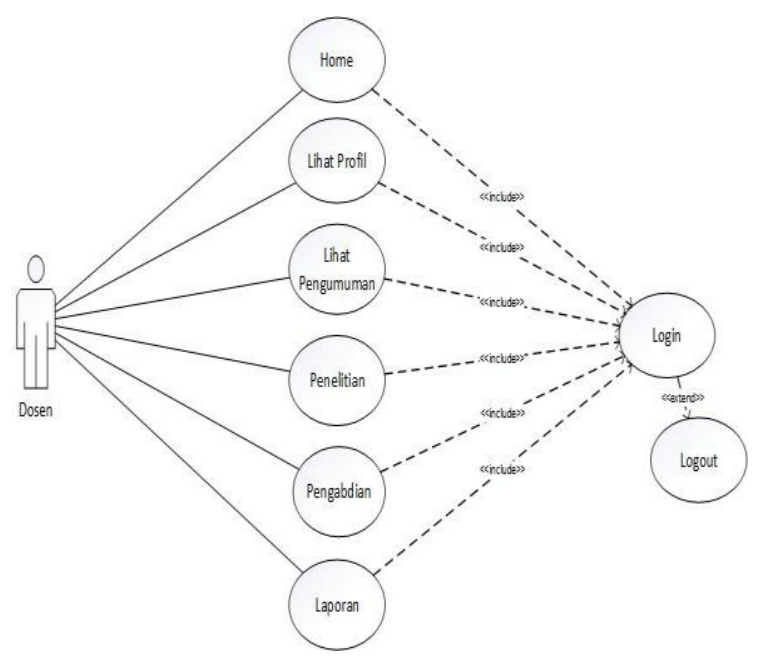

Gambar 3. Use Case Diagram Halaman Dosen

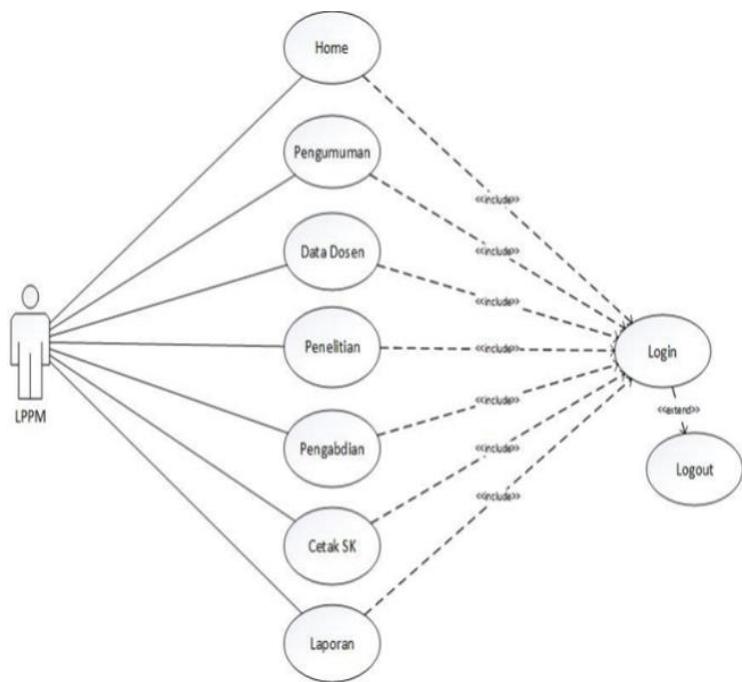

Gambar 4. Use Case Diagram Halaman LPPM/Admin

Rancangan flowchart usulan activity diagram data dosen dapat dilihat pada gambar 5. 
Vol. 1 No. 1, Maret 2021, hlm. 33 - 42

DOI: $\mathrm{xxxxxxxxxxxxxxxxx}$

Available online at http:// jurnal.stmikroyal.ac.id/index.php/j-com

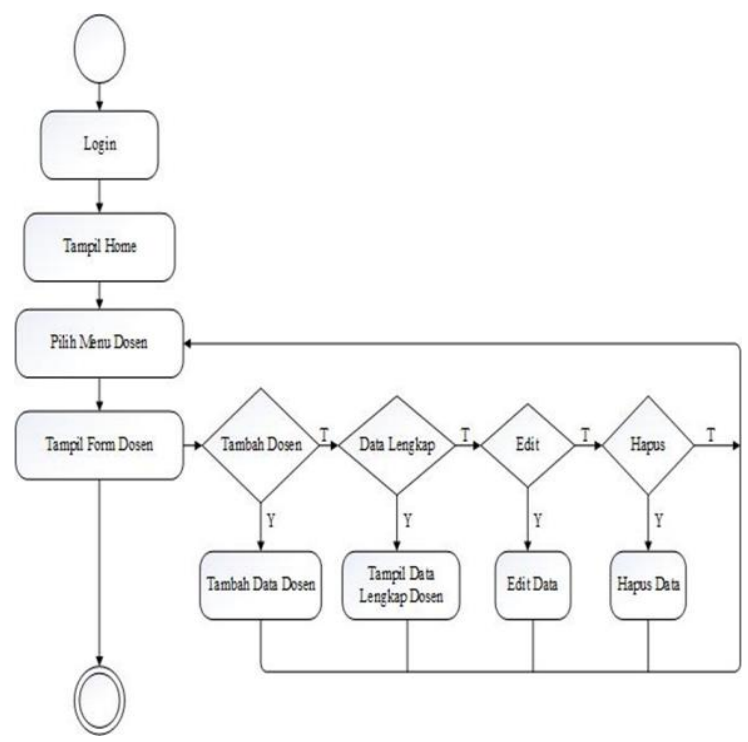

Gambar 5. Activity Diagram Data Dosen

Pada gambar 5. Menunjukan aktifitas yang terjadi pada halaman data dosen adalah ketika user telah berhasil login, maka akan tampil sebuah form data dosen yang dimana pada form ini terdapat tombol tambah dosen, apabila admin mengklik tombol ini maka akan diarahkan menuju form input data dosen, tombol data lengkap untuk menampilkan data lengkap dari seorang dosen, tombol edit untuk meng-update data dosen apabila ada kesalahan dan akan diperbaiki dan terakhir tombol hapus untuk menghapus data dosen. gambar 6.

Rancangan flowchart usulan activity diagram data penelitian dapat dilihat pada

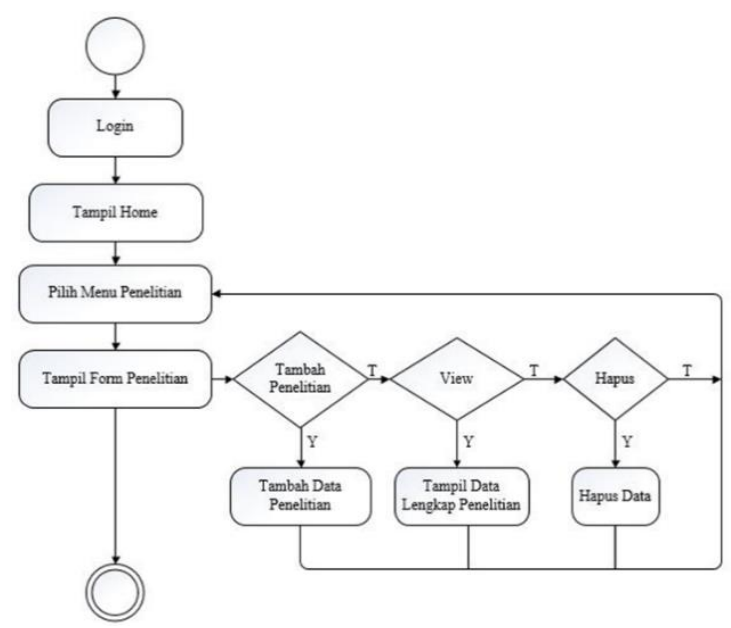

Gambar 6. Activity Diagram Data Penelitian 
Vol. 1 No. 1, Maret 2021, hlm. 33 - 42

DOI: $\mathrm{xxxxxxxxxxxxxxxxx}$

Available online at http:// jurnal.stmikroyal.ac.id/index.php/j-com

Pada gambar 6. menunjukan aktifitas yang terjadi pada halaman penelitian adalah ketika user telah berhasil login ke dalam sistem dan memilih menu penelitian maka akan tampil form penelitian, diamana pada form ini user dosen dapat menginputkan usulan proposal penelitian dengan mengklik tombol tambah penelitian dan akan diarahkan menuju form input usulan penelitian, tombol view untuk melihat hasil inputan dan tombol hapus untuk menghapus data usulan penelitian. Sedangkan pada user admin hanya dapat menghapus usulan apabila belum lengkap dan melihat usulan proposal penelitian yang kemudian nantinya akan dijadikan acuan untuk pembuatan surat keputusan pelaksanaan penelitian

Rancangan flowchart usulan ativity diagram data pengabdian dapat dilihat pada gambar 7.

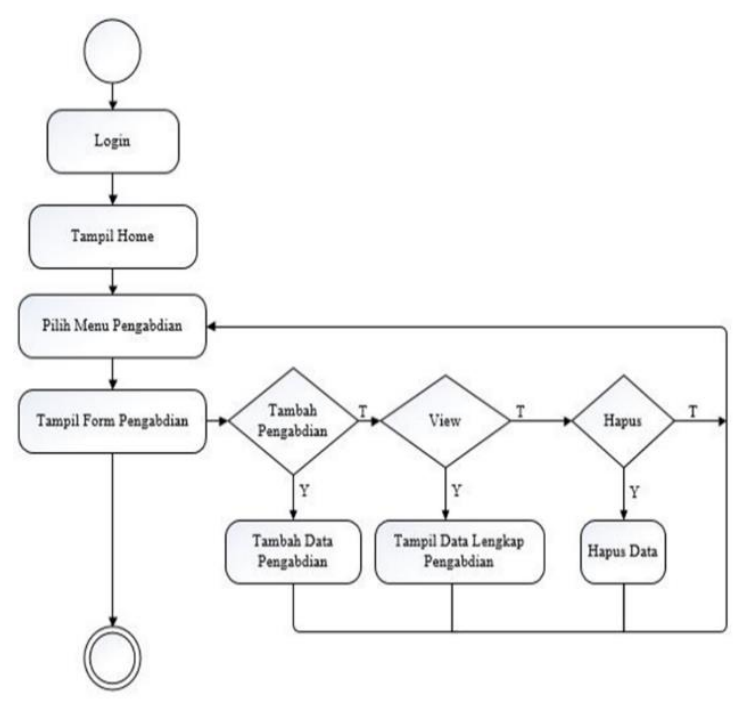

Gambar 7. Activity Diagram Pengabdian

Pada gambar 7. Menjelaskan aktifitas yang terjadi pada halaman pengabdian adalah ketika user telah berhasil login kedalam sistem dan memilih menu pengabdian maka akan tampil form pengabdian, diamana pada form ini user dosen dapat menginput-kan usulan proposal pengabdian dengan mengklik tombol tambah pengabdian dan akan diarahkan menuju form input usulan pengabdian, tombol view untuk melihat hasil inputan dan tombol hapus untuk menghapus data usulan pengabdian.

Sedangkan pada user admin hanya dapat menghapus usulan proposal pengabdian apabila belum lengkap dan melihat usulan proposal yang kemudian nantinya akan dijadikan acuan untuk pembuatan surat keputusan pelaksanaan pengabdian. Rancangan flowchart usulan activity diagram laporan dapat dilihat pada gambar 8. 
Vol. 1 No. 1, Maret 2021, hlm. 33 - 42

DOI: $\mathrm{xxxxxxxxxxxxxxxxx}$

Available online at http:// jurnal.stmikroyal.ac.id/index.php/j-com

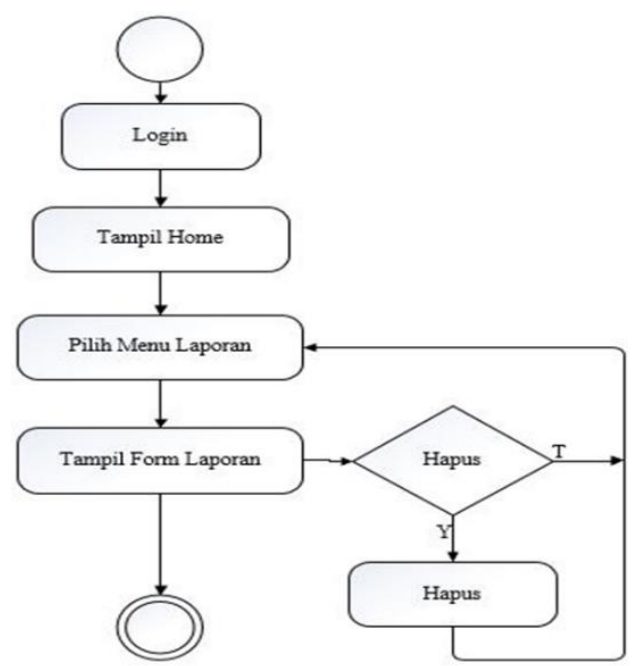

Gambar 8. Activity Diagram Laporan

Penjelasan gambar 8. Menjelaskan aktifitas yang terjadi pada halaman laporan adalah ketika user telah berhasil login kedalam sistem dan memilih menu penelitian maka akan tampil form laporan, dimana pada form ini user dosen dapat menginputkan laporan kegiatan harian dan laporan akhir dari kegiatan penelitan atau pengabdian dan dapat meng-update dan menghapus laporan. Sedangkan pada user admin dapat menampilkan laporan dari dosen dan dapat men-download laporan tersebut.

\section{HASIL DAN PEMBAHASAN}

Form home yang akan tampil pertama kali ketika pengguna atau user memasukkan username dan password yang benar, form home dapat dilihat pada gambar 9.

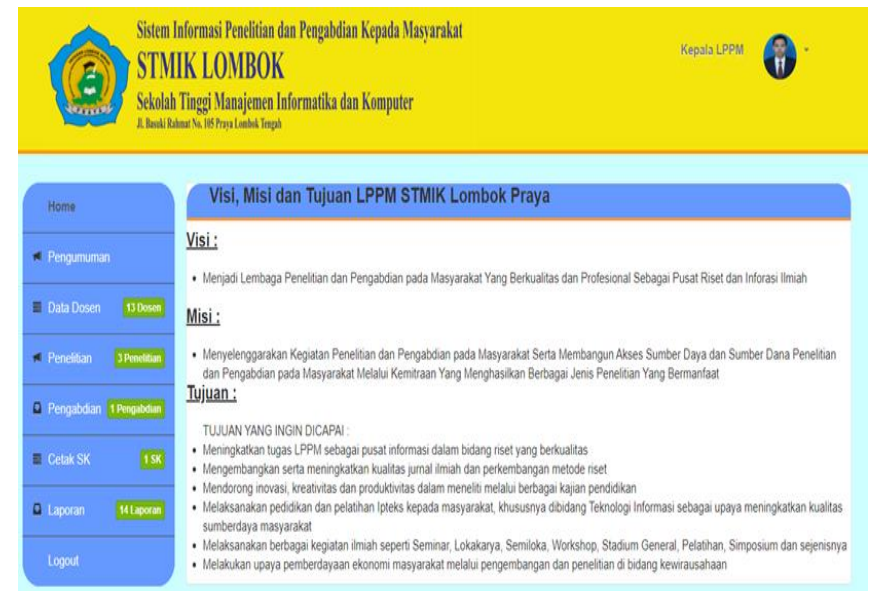

Gambar 9. Form Home

Form data dosen merupakan form yang berfungsi untuk melihat data lengkap dosen, menambah, mengubah, mencari maupun menghapus data dosen. Cara kerja dari form data dosen adalah apabila admin akan menambahkan atau menginputkan data yang 
Vol. 1 No. 1, Maret 2021, hlm. 33 - 42

DOI: $\mathrm{xxxxxxxxxxxxxxxxx}$

Available online at http:// jurnal.stmikroyal.ac.id/index.php/j-com

baru, klik tombol tambah data dosen setelah itu akan muncul form untuk pengisian data, admin bisa langsung menginputkan atau menambah data kedalam data dosen, setelah menginputkan data dosen selesai klik tombol simpan data yang berfungsi untuk menyimpan data yang sudah dimasukkan ke dalam tabel.

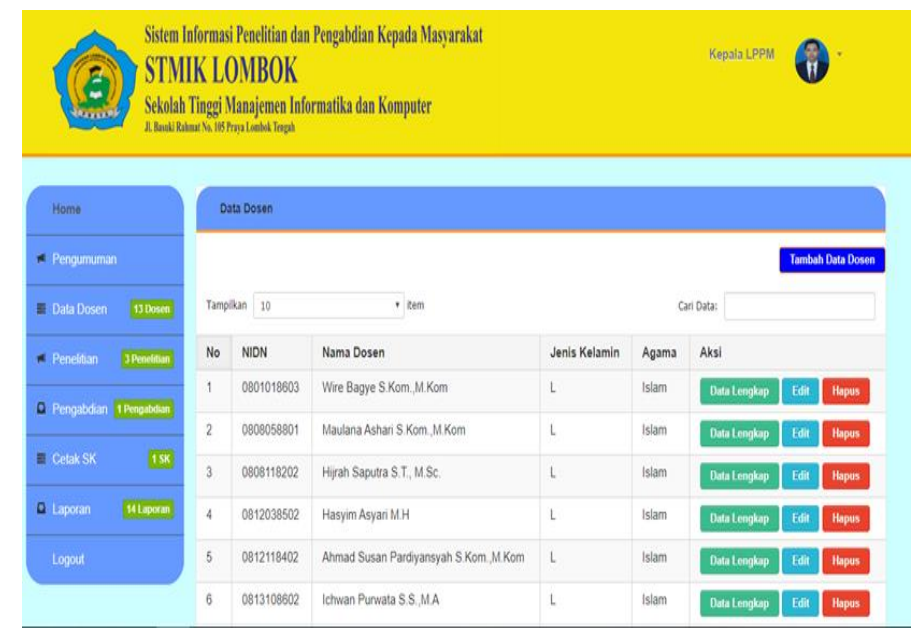

Gambar 10. Form Data Dosen

Form halaman penelitian berada di halaman admin dan dosen, dimana admin hanya bisa review usulan yang sudah di-input-kan oleh dosen yang berhasil disimpan ke dalam database, berikut adalah tampilan input usulan penelitian serta tampilan data penelitian.

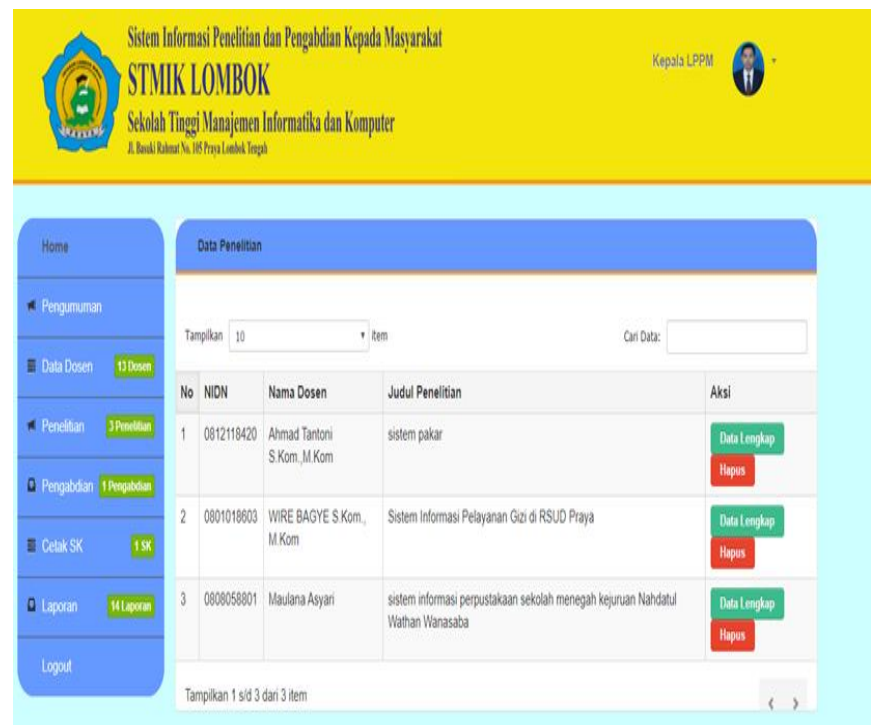

Gambar 11. Form Data Penelitian

Form data pengabdian ini berisi tentang data pengabdian yang sudah di-inputkan oleh dosen yang sudah tersimpan kedalam database. Dalam form data pengabdian ini terdapat tombol data lengkap untuk melihat kelengkapan data pengabdian dan tombol hapus untuk menghapus pengabdian yang mungkin ada perubahan oleh dosen 
Vol. 1 No. 1, Maret 2021, hlm. 33 - 42

DOI: $\mathrm{xxxxxxxxxxxxxxxxx}$

Available online at http:// jurnal.stmikroyal.ac.id/index.php/j-com

bersangkutan, berikut adalah tampilan dari form data pengabdian dapat dilihat pada gambar 12 .

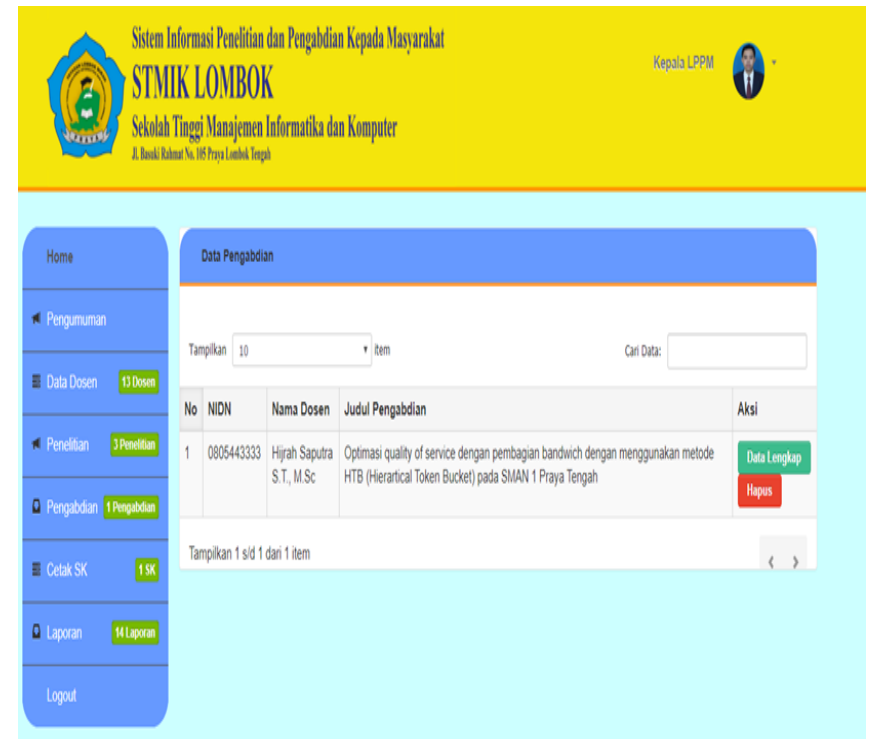

Gambar 12. Form Data Pengabdian

Pada form cetak SK adalah form yang terdapat dihalaman admin yang berfungsi untuk mencetak semua nama-nama dosen yang telah melakukan usulan prosposal penelitian dan pengabdian, berikut tampilan halaman form cetak SK. Form cetak SK dapat dilihat pada gambar 13.

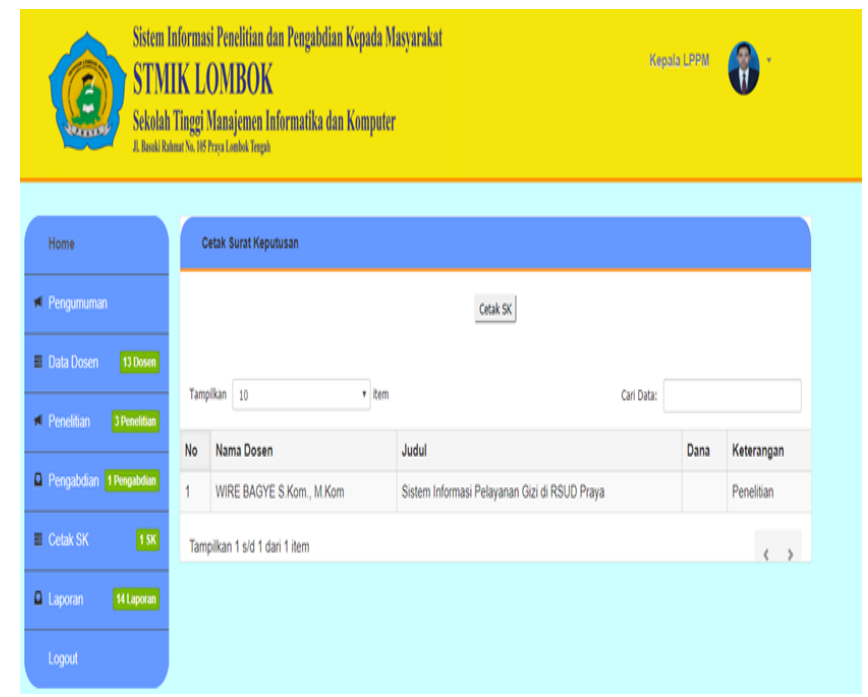

Gambar 13. Form Cetak SK 
Vol. 1 No. 1, Maret 2021, hlm. 33 - 42

DOI: $\operatorname{xxxxxxxxxxxxxxxxx}$

Available online at http:// jurnal.stmikroyal.ac.id/index.php/j-com

\section{SIMPULAN}

Kesimpulan yang dapat diambil dari sistem ini adalah: (1) Sistem informasi penelitian dan pengabdian kepada masyarakat ini telah mampu menginputkan data pengumuman, data dosen, data penelitian, data pengabdian, dan input laporan serta output pengeluaran cetaknya berupa cetak surat keputusan., (2) Sistem ini dapat menampilkan informasi tentang data diri dari masing-masing dosen, dan menampilkan informasi mengenai pengumuman, data semua dosen, data penelitian, data pengabdian dan laporan yang disajikan dalam bentuk basis data.

\section{DAFTAR PUSTAKA}

[1] I. A. E. Pratama, Sistem Informasi dan Implementasinya. Bandung: Informatika Bandung, 2013.

[2] K. Schwaber and J. Sutherland, The Scrum GuideTM The Definitive Guide to Scrum: The Rules of the Game. Scrum.Org and ScrumInc, 2014.

[3] T. Satpathy, A Guide to the Scrum Body Of Knowledge (Sbok Guid), 3rd ed. Avondale: SCRUMstudy ${ }^{\mathrm{TM}}$, a brand of VMEdu, Inc, 2016.

[4] G. Gata and W. Gata, Sukses Membangun Aplikasi Penjualan dengan Java. Jakata: Elex Media Komputindo, 2013.

[5] M. S. Mustaqbal, R. F. Firdaus, and H. Rahmadi, "Pengujian Aplikasi Menggunakan Black Box Testing Boundary Value Analysis,” J. Ilm. Teknol. Inf. Terap., vol. Volume I, 2015. 